PRZEGLĄD RUSYCYSTYCZNY 2020, nr 2(170)

DOI 10.31261/pr.7792

KATARZYNA ARCISZEWSKA-TOMCZAK

Uniwersytet Gdański

(D) ORCID: http://orcid.org/oooo-0oo3-0610-8509

\title{
OBRAZ ROSYJSKIEJ CODZIENNOŚCI W POWIEŚCI TEKST DMITRIJA GŁUCHOWSKIEGO
}

Tekst (Тексm, 2017) jest w dorobku Dmitrija Głuchowskiego, docenionego przez odbiorców i krytykę autora prozy fantastycznej, pierwszą realistyczną powieścią poświęconą współczesnej Rosji. Potrzebę stworzenia utworu, poruszającego aktualne i charakterystyczne dla rosyjskiej codzienności wątki, pisarz wyraża w jednym z wywiadów:

Мне нужен был текст о сегодняшнем дне. Городской роман. Мне казалось, что все, что я читаю из русского, совершенно несовременно. Хотелось такую коробку с гвоздями сделать: чтобы в каждую из главных сегодняшних тем забить по гвоздю1.

Głuchowski koncentruje się zatem na ukazaniu w powieści rzeczywistości rosyjskiej w jej codziennym, powszednim wydaniu. Odbiorca styka się w utworze z szerokim spektrum gatunków (thriller, kryminał, noir, dramat ${ }^{2}$, powieść psychologiczna) i wątków (niespełniona miłość, niesprawiedliwa kara, stracona młodość, samotność), które umożliwiają przedstawienie pełnej gamy tematów kształtujących współczesną rosyjską codzienność, a także jej szczególnej charakterystyki.

1 И. Кириенков, Дмитрий Глуховский о технозависимости, 228-й статье и экранизации „Метро 2033”, https://daily.afisha.ru/brain/6350-o-tehnozavisimosti-228-y-state-i-ekranizacii-metro-2033/ (12.05.2019).

2 Taką informację znajdujemy na okładce polskiego wydania powieści: D. Glukhovsky, Tekst, przeł. P. Podmiotko, Insignis, Kraków 2017. Cytaty pochodzące z tego źródła zostaną opatrzone w tekście numerem strony. 
Tekst nosi znamiona opowieści autentycznej, „spisanej z życia”, wiernie, niemal reportażowo odzwierciedlającej w świecie przedstawionym realia świata rzeczywistego. Jak zauważa Marcin Kube,

przy swej sensacyjnej konwencji „Tekst” stanowi również ciekawą opowieść o współczesnej Moskwie. Zasłyszane rozmowy w komunikacji publicznej, wszechobecna milicja oraz urzędnicy, którzy załatwią wszystko „za dopłatą” - to wszystko składa się na mozaikowy obraz rosyjskiej stolicy. Nad tym zaś unosi się klasyczna rosyjska „czernucha”, w której wszystkie drogi prowadzą do porażki³.

Głuchowski umiejętnie zestawia opisy dopełniających się wzajemnie przestrzeni i wymiarów: Moskwy i podmoskiewskiego miasteczka, więzienia - zony i terytorium umownej wolności poza nią, życia własnego i cudzego, podpatrzonego, skradzionego. Powstaje z tej kompilacji obraz rzeczywistości determinującej określone metody i skutki działania człowieka, wywołującej określone, z góry wiadome reakcje na jej przejawy, ponieważ wizja współczesności nakłada się w analizowanej powieści na szeroki kontekst tradycji, kultury i literatury rosyjskiej i przywołuje wypracowany przez nie model. Głuchowski w czytelny sposób nawiązuje do rosyjskich „przeklętych problemów”, moralnych dylematów, o jakich pisali wielcy klasycy: Lew Tołstoj, Fiodor Dostojewski, Anton Czechow, Iwan Turgieniew4. W swoim spojrzeniu na rosyjską rzeczywistość autor Tekstu bliski jest także współczesnemu literackiemu dyskursowi o Rosji i rosyjskiej codzienności, przywołując w swym utworze wśród jej charakterystycznych cech także te, które wydają się na stałe przypisane sferze rodzimej powszedniości i pojawiają się w dziełach współczesnych pisarzy rosyjskich: Ludmiły Pietruszewskiej, Ludmiły Ulickiej, Wiktora Pielewina, Władimira Sorokina, Zachara Prilepina i innych ${ }^{5}$. Twórcy ci postrzegają współczesną Rosję przez pryzmat niekompletności, deformacji, ułomności, dysfunkcjonalności, a jej mieszkańców charakteryzują jako jednostki wyalienowane, niedopasowane, odarte z marzeń i nadziei, odbiegające od normy, atroficzne (w sferze materii i ducha),

3 M. Kube, „Tekst” Gtuchowskiego: przechowalnia naszej duszy, https://www. rp.pl/Literatura/171129040-Tekst-Gluchowskiego-Przechowalnia-naszej-duszy. html (13.06.2019).

4 Zob. A. Przybysz, Rekonfiguracja. Dmitrij Gtuchowski na gruncie realizmu, „Porównania” 2018, $\mathrm{nr}$ 2(23), s. 130-132.

5 Inspiracje i odwoływanie się autora Tekstu do utworów i stylistyki innych twórców spotkało się zarówno z przychylnością, jak i krytyką recenzentów powieści. Zob. nр. О. Демидов, Катастрофа в космосе русской словесности, http://rararara.ru/menu-texts/katastrofa_v_kosmose_russkoj_slovesnosti (15.05.2019). 
postawione na granicy pomiędzy pragnieniem zerwania $\mathrm{z}$ otaczającą rzeczywistością i niemożnością dokonania tego.

Konstruując pejzaż miejski, w którym pojawiają się protagoniści Tekstu, Głuchowski sięga po atrybuty o zabarwieniu wyraźnie pejoratywnym: chłód (,[...] z nieba sypało tu zimną solą, chłostało policzki. Chodniki nie odtajały, zamiast asfaltu wszędzie był udeptany śnieg”, s. 14), fetor („Dworzec był ciągle terytorium otaczającej ją przepoconej i przetłuszczonej Rosji”, s. 6), szarość, będącą synonimem egzystencji pozbawionej wartości i znaczenia („Za oknem wisiała szara zasłona mgły: zwykły zimowy dzień - listopadowy albo marcowy”, s. 134), wadliwość („Domy z wielkiej płyty stały ze szwami na wierzchu, spierzchnięte, niewesołe”, s. 14), wszechobecne „śmieci, zgniliznę, nieszczęście" (s. 217). Obraz ten uzupełniają postacie policjantów, przedstawionych w sposób niepozostawiający wątpliwości co do ich roli. Nie są to stróże prawa i porządku, chroniący obywateli, lecz funkcjonariusze, sprawujący ustawiczną kontrolę, dbający o to, by obserwowani ludzie odczuwali zagrożenie i ograniczenie wolności („Ilja rutynowo dojrzał je już z dala, ponad głowami innych. Szare mundury, dobrze odżywione mordy, myszkujące, lepkie spojrzenia”, s. 6, ,[...] widział wszędzie [...] mentów. [...] Całe stada, wszyscy z oczami owczarków", s. 8). Należy też zwrócić uwagę na wprowadzony do powieści od pierwszych jej stron tłum ${ }^{6}$, masę, otaczających głównego bohatera obcych ludzi, potęgujących wrażenie samotności, bycia „poza”, czyli stan kształtujący codzienność w literaturze rosyjskiej.

Głuchowski wykorzystuje też chwyt kontrastu, który definiuje Rosję, a kategoria ta „weszła w duchowy krwioobieg narodu trwającego od pokoleń na granicy dwóch światów: Azji i Europy”. Pisarz sięga po nią między innymi przywołując wizję Moskwy jako konglomeratu

${ }_{6}$ Tłum jako nieodłączny element rosyjskiej rzeczywistości pojawia się w zbiorze opowiadań, poświęconych Petersburgowi autorstwa niemieckiego pisarza Ingo Schulze: „Byle dalej od Rosji! [...] Tutejsi ludzie [...] nie potrafią poruszać się po ulicach. Rozpychają się, krzyczą tłoczą, plują. [...] Tłum wciąga człowieka do autobusu, wypycha wprost pod koła samochodu", I. Schulze, 33 mgnienia szczęścia. Pamiętnik znaleziony $w$ drodze do Petersburga, przel. A. Kryczyńska, Muza, Warszawa 2003, s. 32. Schulze przywołuje w swym zbiorze także inne atrybuty rosyjskiej codzienności, o których pisze Głuchowski - są to chaos, brud, fetor, bylejakość. Szerzej piszę o tym w artykule 33 mgnienia szczęścia. Obraz Rosji $w$ opowiadaniach Ingo Schulze, w: Rosja w krysztale. Rozważania, fakty, miraże, D. Oboleńska, U. Patocka-Sigłowy, K. Arciszewska, K. Rutecka (red.), Wydawnictwo Uniwersytetu Gdańskiego, Gdańsk 2014, s. 175-192.

7 Z. Żakiewicz, Rosja, Rosja..., Polnord, Gdańsk 2006, s. 143. 
przeciwstawnych elementów, tworzących zdumiewającą całość. Rosyjską stolicę w ujęciu autora Tekstu charakteryzuje brak ładu i proporcji, a także trudne do zdefiniowania współistnienie różnych planów rzeczywistości. Mamy tu do czynienia z przestrzenią prawdziwą, choć nieprawdopodobną, czystym przejawem groteski, bazującej na zharmonizowanych dysonansach ${ }^{8}$ :

Moskwa była mieszanką wszystkiego: najbardziej niepodobnych do siebie budynków, najbardziej niedopasowanych ludzi, z czasów będących swoim przeciwieństwem: w jednym wierzyło się w duszę i świątynie, a w drugich - w ciało i baseny; i wszystko w niej współistniało, nic się w niej całkowicie nie rozpuszczało i na zawsze nie ginęło. Żyło tak jakby w różnych warstwach, na różnych poziomach - ale jednocześnie. Zadziwiające miasto ta Moskwa. Ze wszystkich stron obszarpane, skrojone z kradzionych ścinków, pstrokate i dlatego prawdziwe (s. 225).

W prezentowanej przez Głuchowskiego optyce zawiera się wielopokoleniowe doświadczenie tego typu kontrastowej, łączącej przeciwieństwa rosyjskości, egzemplifikowane $\mathrm{w}$ tekstach rosyjskich klasyków, trafnie dostrzeżone i opisane, także na podstawie własnych refleksji na temat Rosji, przez Zbigniewa Żakiewicza:

Ten tłum, ta masa jest tłem, na którym Tołstoj i inni pisarze widzieli „podwiżników” - duchowych pokutników, cierpiętników. Przecież nawet Sołżenicyn w swoim opowiadaniu Matrionin dwor sygnalizuje istnienie tej Rosji. Wieś Bunina to konieczny dopisek, bez którego cała literatura pisarzy „chorego sumienia” - Tołstoja, Dostojewskiego - jest niezrozumiała, jak niezrozumiały byłby anioł, gdyby nie było diabła. Ci pijacy walający się jak brudne tłumoki na ulicach, ten chamski krzyk i brud w barach. I ta kobieta rozwścieczona jak suka, którą trzymano na łańcuchu przez całe życie, nie wpuszczająca do stołówki pijaków, ich natarczywość, brutalność i równie brutalna reakcja. Widziałem: ona była zmęczona tym wszystkim i dlatego nie mogła być „kulturalna”. Te zupełnie niezasłużone i niespodziewane chamskie zrugania, których już kilkakrotnie doświadczyłem, całkiem niewinnie. Krzyk starej kobiety na dziecko, które niechcący wlazło przed nią do metra, krzyk z użyciem słów brudnych, brutalnych - wszystko to ciągle buninowska Wieśs.

Rozbicie i dezintegracja odciskają się piętnem nie tylko na przestrzeni, w której rozgrywa się u Głuchowskiego spektakl codzienności, lecz również na przedstawionych w powieści relacjach między-

8 Zob. M. Głowiński, Groteska jako kategoria estetyczna, w: tegoż (red.), Groteska, Słowo/ obraz terytoria, Gdańsk 2003, s. 9.

9 Z. Żakiewicz, Rosja, Rosja..., s. 24. 
ludzkich. Każdy związek, a także plan czy inicjatywa skazane są na niepowodzenie. Tego przejawu znamiennego dla Rosji pesymistycznego determinizmu doświadcza dotkliwie przede wszystkim główny bohater powieści, Ilja Goriunow. Wraca on do rodzinnego podmoskiewskiego miasteczka Łobnia po siedmiu latach w zonie, gdzie odbywał karę za niepopełniony czyn. Podczas akcji antynarkotykowego oddziału policji dwudziestoletni wówczas Ilja staje w obronie swojej dziewczyny, którą w brutalny sposób ma zamiar zrewidować dowodzący akcją podporucznik Piotr Chazin, najwyraźniej pozostający pod wpływem substancji odurzających. Funkcjonariusz, mszcząc się za zuchwałą postawę chłopaka, podrzuca mu paczkę z heroiną, skazując tym samym niewinnego Ilję na lata ciężkiego więzienia. Powrót do domu jest dla bohatera świętem, urzeczywistnieniem jego więziennych marzeń, lecz z drugiej strony, nieoczekiwanie, staje się momentem fatalnym, zapowiedzią katastrofy - utraty wszystkiego, co stanowi dla bohatera wartość. Codzienność Tekstu posiada wyraźnie zaznaczoną moc sprawowania władzy nad człowiekiem, wtłaczania go $\mathrm{w}$ zaplanowane bez jego wiedzy i woli scenariusze. W tym przypadku możemy więc mówić o syngularnym charakterze ${ }^{10}$ dnia powszedniego, gdyż składające się nań wydarzenia przynoszą zmianę myślenia, postępowania i postrzegania rzeczywistości nie tylko jednostkowego bohatera, ale także „fundują nowy sens, nowy porządek symboliczny"11 w szerszym kontekście, w odniesieniu do całej społeczności. Codzienność traci u Głuchowskiego aspekt swojskości, przewidywalności, staje się tajemnicza, przynosi niespodziewane rozwiązania, umożliwia realizację pozornie fantastycznych planów (np. przywłaszczenie cudzego życia).

Doświadczana przez znamienne siedem lat (siódemka symbolizuje między innymi oszustwo oraz ból12, zatem długość wyroku od początku zdaje się determinować późniejszy los bohatera) codzienność zony zmienia pełnego nadziei, stojącego u progu życia młodego mężczyznę w nieufnego, zagubionego w świecie bez krat człowieka. Ta metamorfoza protagonisty, przymusowa rozłąka z bliskimi i towarzyszące mu dojmujące poczucie niesprawiedliwości powodują zerwanie więzów z przyjacielem dzieciństwa i młodości („,...] Ilja nie mógł już

${ }^{10}$ Zob. B. Waldenfels, Podstawowe motywy fenomenologii obcego, przeł. J. Sidorek, Oficyna Naukowa, Warszawa 2009, s. 60.

${ }^{11}$ A. Orlikowski, Wartość obcego. Fenomenologia obcego i motywy etyki przednormatywnej, „Filo-Sofija” 2016, nr 33(2016/2), s. 61.

${ }_{12}$ W. Kopaliński, Stownik symboli, t. 6, Rzeczpospolita, Warszawa 2007, s. 378. 
na Sieriogę patrzeć, aż go trzęsło. Nienawidził go za to, że stał mu się obcy. Za to, że przez siedem lat żył w górę, a Ilja w głąb”, s. 54). Ponadto bohater zostaje odtrącony przez Wierę, dziewczynę, z której powodu odbywa karę. Tym samym jego poświęcenie i cierpienie zyskują wymiar niepotrzebnego, pozbawionego sensu czynu. Największym ciosem dla Ilji jest jednak utrata matki, która umiera na zawał po otrzymaniu wiadomości o powrocie syna. Motyw śmierci, spowodowanej radosną wiadomością, egzemplifikuje kolejny aspekt rosyjskiej codzienności - naznaczenie jej przez fatum, nieszczęście, pojawiający się często we współczesnej literaturze rosyjskiej. Pielewin na przykład określa człowieka mianem fabryki bólu ${ }^{13}$, a odczuwane przez niego krótkie chwile zadowolenia postrzega jako iluzoryczne, służące jedynie pogłębianiu nieszczęścia ${ }^{14}$. W tym kontekście przyjazd bohatera Tekstu do domu, w którym zmarła jego matka, domu z zamkniętymi drzwiami można odczytać jako kolejny symboliczny znak końca radosnego etapu życia, ostateczne pozbawienie Ilji nadziei na ponowne odnalezienie siebie i swojego miejsca w świecie. Moment ten staje się też zapowiedzią jego własnej śmierci w finale powieści.

Fiasko wszelkich prób zmiany losu i powrotu do normalności jest w warunkach rosyjskiej codzienności nieuniknione. Determinuje ją fatalistyczne przeświadczenie o charakterze Rosji: „Niby wszystko zrobił prawidłowo, a i tak pójdzie do piekła. Życie na ziemi jest tak zorganizowane, żeby wszyscy ludzie koniecznie trafiali do piekła. Szczególnie w Rosji” (s. 141). Wyrażając taki osąd, Głuchowski odwołuje się do powtarzającej się w opiniach na temat Rosji refleksji Piotra Czaadajewa, twierdzącego, że jego ojczyzna jest krajem bez perspektyw, oderwanym od korzeni i pozbawionym nadziei, w którym żyje się „wyłącznie teraźniejszością w jej najwęższym zasięgu, bez przeszłości i przyszłości, wśród martwego zastoju" ${ }^{15}$. Pobrzmiewają w tym fragmencie powieści również echa europejskiego dyskursu politycznego, w którym Rosja od dawna uznawana jest za „tłumiciela wolności”, „ciemną i złą siłę”, „politycznego Arymana” ${ }^{16}$. Zmagania bohatera bo-

13 „[...] человек - это просто фабрика боли”. В. Пелевин, Бэтман Аполло, Эксмо, Москва 2013, с. 284.

14 „Редкие моменты удовольствия есть просто фаза страдания. Удовольствие, как червяк на рыболовном крючке, служит для того, чтобы глубже вовлечь ум в боль...”. Tamże, s. 285.

${ }^{15}$ Cyt. za A. Bezwiński, Puszkina i innych pytania o Rosję, „Studia Rossica Posnaniensia" 1991, nr 21, s. 11.

${ }^{16}$ Określenia Nikołaja Danilewskiego, cyt za G. Przebinda, Piekło z widokiem na niebo. Spotkania z Rosja 1999-2004, Wydawnictwo Znak, Kraków 2004, s. 14. 
rykającego się z egzystencjalnymi dylematami z góry więc skazane są na przegraną ze względu na specyfikę otaczającej go rosyjskiej rzeczywistości.

W przypadku Ilji niezdolności do zmiany własnego losu towarzyszy poczucie winy i potrzeba odpokutowania popełnionego przestępstwa - zabójstwa policjanta Chazina. Dawny więzień postanawia spotkać się ze swoim wrogiem, ponieważ pragnie zakończenia psychicznego koszmaru. Pomóc w tym może wyjaśnienie, dlaczego w tak okrutny sposób potoczyły się jego losy. Towarzyszące bohaterowi smutek, rozgoryczenie i poczucie niesprawiedliwości stopniowo ustępują miejsca złości i chęci zemsty. Powodem tej zmiany jest niewinne z pozoru zdarzenie - Ilja widzi na profilu facebookowym zdjęcie zadowolonego, rozbawionego Chazina w towarzystwie wyzywającej blondynki. Widok ten uzmysławia bohaterowi, że tragedia, którą rozpamiętuje każdego dnia i z którą nie może sobie poradzić, nie wywołuje wyrzutów sumienia oprawcy, jest zatem nic nieznaczącym, zapomnianym przez policjanta epizodem. Umieszczona pod zdjęciem nazwa moskiewskiego klubu staje się impulsem do poszukiwania sprawiedliwości. Ilja zabija Chazina, porzuca ciało w kanale ściekowym, sam zaś ucieka, nieświadomie zabierając smartfon zmarłego. Morderstwo, którego dokonuje bohater, powoduje zmianę ról głównych postaci powieści - oprawca staje się ofiarą. Pozornie mogłoby się wydawać, że Ilja słusznie wyręcza los w wymierzeniu sprawiedliwości, dokonując zemsty, przysługującej mu według niepisanego prawa zeków. Czyn ten nie daje jednak bohaterowi satysfakcji, nie zapewnia mu spokoju. Przeciwnie, budzi wyrzuty sumienia, przygnębienie, wywołuje refleksje, które prowadzą do wniosku, że życie kształtowane przez rosyjską codzienność to łańcuch fatalnych zdarzeń. Rosyjska rzeczywistość oferuje sytuacje bez wyjścia i pozbawia możliwości wyboru czy ratunku, czego doskonałym przykładem jest sytuacja Ilji:

W tym zerowym powietrzu strach zaczął tajać, a zamiast niego kropla po kropli zaczął gromadzić się rozmrożony gniew. Za co oni tak z Ilją? Dlaczego spędził życie zagoniony w kąt i w kącie je skończy? Dlaczego jest tak bezsilny w konfrontacji ze światem? Gdzie sprawiedliwość w tym, że nie może uniknąć kary? Dlaczego zabić człowieka się udaje, a wybaczyć - nie? Dlaczego wszystko jest w rękach ludożerców? Dlaczego nie ma innego wyjścia, jak tylko podnieść na siebie rękę, a za samobójstwo idzie się do piekła? Ty jesteś Bóg czy właściciel rzeźni? (s. 124)

W obliczu rozterek, które towarzyszą Ilji od momentu dokonania morderstwa do finałowej sceny powieści, w której bohater sam 
ginie, słuszne jest stwierdzenie jednej z recenzentek powieści, Mariny Strukowej, że „Глуховский реанимировал Раскольникова, вложил в его уста сленговые выражения, поселил в современном городе" ${ }^{17}$. Współczesny Raskolnikow odbywa swoją katorgę w warunkach, które generuje jego codzienność. Ilja włącza telefon Chazina i, czytając zapisaną w komunikatorach historię, zbiera informacje o swoim oprawcy-ofierze. Bohater poszukuje w nich odpowiedzi na dręczące go pytania, zagłębiając się stopniowo w zapis cudzej egzystencji, innego świata. Ilja powoli zaczyna odczuwać fascynację otwierającą się przed nim perspektywą przejęcia zamkniętego $\mathrm{w}$ telefonie życia. „Niezwykle ważny w tym kontekście jest fakt, iż dwaj główni bohaterowie zostali skonstruowani na zasadzie odbić wypaczonych, sobowtórowej multiplikacji, a więc chwytu artystycznego, który Michaił Bachtin utożsamiał z poetyką [...] Dostojewskiego"18. Ilja staje się więc niejako skazany na bycie sobowtórem Chazina. Ten specyficzny proces zamiany ról i miejsc dzieli się na kilka etapów. Początkowo Ilja tylko czyta wiadomości, ogląda fotografie, poznaje Chazina, jego rodzinę, narzeczoną i współpracowników. Stopniowo zaczyna przejmować się treścią wiadomości, ma ochotę interweniować, tłumaczyć, przepraszać w imieniu Chazina, naprawiać jego relacje z matką, ojcem, Niną. Rzeczywistość zapisana w smartfonie wciąga Ilję, ponieważ stwarza nową perspektywę, rekompensuje bolesne luki z jego życia. Bohater znów czuje się zakochany w pięknej dziewczynie, czuje bliskość i troskę matki oraz kontakt z ojcem, którego w swoim życiu nigdy nie poznał:

Pietia był uparty, Pietia nie prosiłby o wybaczenie. Pietia od urodzenia miał ojca, nigdy nie patrzył na niego jak na cud i nigdy nie myślał, że ojca mogłoby nie być. To Ilji Ziemia była niekompletna, bo składała się tylko z jednej półkuli [...] I tak właśnie przez całe życie zgadujesz, jak to jest, kiedy ma się ojca. Kogo by z ciebie zrobil, gdyby był (s. 227).

W Tekście Głuchowski realizuje zatem podstawową według Urszuli Kowalczuk właściwość literackiego dyskursu codzienności, czyli ukazuje rewersową strukturę rzeczywistości ${ }^{19}$. Pisarz ustawia antagoni-

${ }_{17}$ М. Струкова, О романе Глуховского „Текст”, http://writervall.ru/gluhovskijtekst/ (15.05.2019)

${ }^{18}$ A. Przybysz, Rekonfiguracja. Dmitrij Gtuchowski na gruncie realizmu..., s. 132.

${ }^{19}$ Zob. U. Kowalczuk, „Codzienność w literaturze XIX (i XX) wieku. Od Adalbeta Stifiera do wspótczesności”, pod red. Grażyny Borkowskiej i Anety Mazur, Opole 2007: [recenzja], „Wiek XIX: Rocznik Towarzystwa Literackiego imienia 
stów na przeciwległych biegunach zdarzeń, jednak losy obu mężczyzn splecione są ze sobą, stanowią swego rodzaju wzajemne dopełnienie. Na zasadzie kompensacji Ilja zagłębia się w życie zabitego policjanta, zapominając o swoim, a raczej wybierając je zamiast własnej egzystencji, naznaczonej pustką i stratą. Jednak zaangażowanie bohatera nosi znamiona fatalistycznego przymusu, a także autodestrukcyjnej ostentacji. Mężczyzna nie zauważa upływu czasu podczas śledzenia historii rodzinnych i służbowych zależności Piotra („Na zewnątrz było już ciemno; dzień się skończyl, nie zdążywszy się zacząć”, s. 170), zaniedbuje swoje obowiązki („Trzeba było pożyć na własny rachunek: dziś mijał termin, żeby zarejestrować się w miejscowym OWD. Prawo daje trzy dni robocze po zwolnieniu. Jeśli odjąć drogę z Solikamska, wychodzi akurat trzeci”, s. 194) momentami aż do całkowitego utożsamienia się z właścicielem telefonu. Bohater decyduje się nawet na nawiązanie kontaktów ze znajomymi Chazina, w jego imieniu odpowiada na sms-y i e-maile, wpływając w ten sposób na kształt i jakość życia codziennego zabitego policjanta. Podczas spotkania z przyjacielem zmarłego Ilja przedstawia się imieniem Pietia, potwierdzając tym samym identyfikację ze swoim odpowiednikiem w rewersowej rzeczywistości. Kolejnym krokiem na drodze przejmowania cudzego życia jest ingerencja $\mathrm{w}$ rodzinne sprawy policjanta. Ilja przełamuje dosadny, bezwzględny, momentami brutalny przekaz Chazina. Łagodnością i skłonnością do kompromisu doprowadza do naprawienia stosunków Piotra z zagniewanym i obrażonym na syna ojcem, a także akceptacji przez rodzinę policjanta oczekującej dziecka narzeczonej Chazina, czym ratuje życie nienarodzonego potomka (Nina planowała aborcję). Bohater dokonuje tego, płacąc najwyższą cenę, rezygnuje bowiem z możliwości ucieczki za zdobyte w imieniu majora pieniądze (pochodzące z nielegalnych transakcji narkotykowych), kiedy kontrahenci Chazina żądają spotkania z nim, grożąc, w razie odmowy, poważnymi konsekwencjami wobec Niny, tak samo niewinnej jak Ilja przed aresztowaniem i osadzeniem w zonie. Bohater toczy wewnętrzną walkę, buntuje się, nie chce zrezygnować z otwierającej

Adama Mickiewicza 2008, nr 1(43), s. 152, http://bazhum.muzhp.pl/media// files/Wiek_XIX_Rocznik_Towarzystwa_Literackiego_imienia_Adama_ Mickiewicza/Wiek_XIX_Rocznik_Towarzystwa_Literackiego_imienia_Adama_ Mickiewicza-r20o8-t1_(43)/Wiek_XIX_Rocznik_Towarzystwa_Literackiego_ imienia_Adama_Mickiewicza-r2008-t1_(43)-s149-156/Wiek_XIX_Rocznik_ Towarzystwa_Literackiego_imienia_Adama_Mickiewicza-r20o8-t1_(43)-s149156.pdf (17.05.2019). 
się perspektywy wyjazdu z Rosji, lecz ostatecznie przegrywa z „wewnętrznym Raskolnikowem" - głosem sumienia oraz rodzącym się uczuciem do Niny:

To dla was kara, dla was odpłata - prosiłem o nią z Solikamska, Bogu na was zakablowałem, i proszę: nasłał na was niegrypsujących. Zgodnie z prawem się nie da, to chociaż według zakonu!

Tyle że podążając tym [...] łańcuchem pokarmowym, najpierw połkną Ninę, bezzębną i miękką, a dopiero potem pójdą szukać Chazina. A to są tylko do ciebie pytania Chazin, dlatego że to ty z tymi brodaczami, jak się okazuje coś kręciłeś, to ty ich kantowałeś, to ty się chowasz za swoją kobietą w ciąży, nie ja!

A kim wy wszyscy dla mnie jesteście? Obcymi ludźmi!

Ja nie mam swoich, oprócz samego siebie. Idźcie wszyscy do diabła! (s. 353)

Ostatecznie Ilja zwraca pieniądze, które mogły zapewnić mu nowy początek i zostawia ślady, pozwalające zidentyfikować go jako mordercę policjanta. Doprowadza to w konsekwencji do śmierci bohatera w wyniku policyjnej akcji. Jego poświęcenie dla dobra nieznanych mu przecież, lecz bliskich w przestrzeni symulakrycznej rzeczywistości zapisanej w smartfonie ludzi, choć Strukowa twierdzi, że nie przystaje do kanonu zachowań bohaterów literatury XXI wieku ani do oczekiwań jej odbiorców ${ }^{20}$, zyskuje wymiar symbolicznej świętości: „[...] podziurawionego odłamkami granatów Ilję wynosili z mieszkania zawiniętego $\mathrm{w}$ prześcieradło. Przypominało to trochę świętego Sebastiana" (s. 366).

Można zaryzykować stwierdzenie, że Tekst jest kolejnym postpokaliptycznym projektem Głuchowskiego. Apokalipsa w tym przypadku ma miejsce w sferze uczuć i relacji interpersonalnych. Konsekwencją ich całkowitego rozbicia jest potrzeba zbudowania na nowo świata, w którym zapanuje emocjonalny ład. Nowy porządek możliwy będzie dopiero po wyrównaniu krzywd, zamknięciu spraw z przeszłości. Ilja podejmuje ten trud, jednak doprowadzenie go do końca okazuje się niemożliwe. Głuchowski pokazuje swojego bohatera w momencie

uwikłania w codzienność, komplikowania się i przekształcania jej obrazu, swoistego rozszczelniania się pozornie zwyczajnej mozaiki powszedniości. Dzięki temu codzienność okazuje się dynamiczną konfiguracją znaczeń o wciąż zmiennym zakresie, a jej rewersowość konotuje tak nieporównywalne jakościowo pary

${ }^{20}$ „Финал романа реалистичен для XIX века, когда покаяние и самопожертвование было основано на религиозных убеждениях. Но XXI век вряд ли способен сформировать человека, способного на самоубийственный альтруизм”. М. Струкова, О романе Глуховского „Текст”... 
opozycji jak: banalne - wzniosłe, własne - obce, śmieszne - serio, realne - fantastyczne, doświadczone - opowiedziane ${ }^{21}$.

Głuchowski wiernie odzwierciedla rosyjskie realia, rezygnując z wszelkich prób estetyzacji przestrzeni czy idealizacji postaw bohaterów. Pokazuje szpetne, odpychające obrazy i sceny, jakie stają się udziałem bohaterów utworu i jakich mogą doświadczyć jego rosyjscy odbiorcy. W centrum zdarzeń stawia człowieka, na którym ciąży odium obcości, osamotnionego, pozbawionego perspektywy ucieczki z sytuacji zapętlenia. Dosadność przekazu eliminuje możliwość złagodzenia wizji powszedniości i urzeczywistnienia nadziei na szczęśliwe zakończenie. Jednak w przekonaniu pisarza odkrywanie prawdziwego, a nie wyidealizowanego oblicza rosyjskiej codzienności jest odpowiedzią na potrzeby i oczekiwania czytelników, gdyż, jak zapewnia on w jednym z wywiadów:

Nie obchodzi nas piękna przyszłość, ludzie uwielbiają dramat, konflikty, reagują na przekaz, kiedy on nimi wstrząsa. [...] ludzie nie chcą wykładów o moralności. Chcą doświadczać emocji, więc najlepszym sposobem na przekazanie im pewnych idei jest ubieranie ich $\mathrm{w}$ silne emocje $\mathrm{e}^{22}$.

\section{REFERENCES}

Arciszewska, Katarzyna. “33 mgnienia szczęścia. Obraz Rosji w opowiadaniach Ingo Schulze.” Rosja w krysztale. Rozważania, fakty, miraże. Red. Oboleńska, Diana. Patocka-Sigłowy, Urszula. Arciszewska, Katarzyna. Rutecka, Karolina. Gdańsk: Wydawnictwo Uniwersytetu Gdańskiego, 2014.

Bezwiński, Adam. "Puszkina i innych pytania o Rosję," Studia Rossica Posnaniensia 1991, nr 21: 3-13.

Demidov Oleg. Katastrofa $v$ kosmose russkoy slovesnosti. <http://rara-rara.ru/ menu-texts/katastrofa_v_kosmose_russkoj_slovesnosti> [Демидов Олег. Катастрофа в космосе русской словесности. <http://rara-rara.ru/menu-texts/katastrofa_v_kosmose_russkoj_slovesnosti $>$ ]

Głowiński, Michał. "Groteska jako kategoria estetyczna.” Groteska. Red. Głowiński, Michał. Gdańsk: Słowo/ obraz terytoria, 2003.

Glukhovsky, Dmitry. Tekst. Przeł. Podmiotko, Paweł. Kraków: Insignis, 2017.

Kiriyenkov, Igor'. Dmitriy Glukhovskiy o tekhnozavisimosti, 228-y stat'ye i ekranizatsii “Metro 2033” [Кириенков, Игорь. Дмитрий Глуховский о технозависимости, 228-й статье и экранизации “Метро 2033”, <https://

${ }^{21}$ U. Kowalczuk, „Codzienność $w$ literaturze XIX (i XX) wieku..., s. 153.

${ }^{22}$ D. Węcławek, Dmitrij Gtuchowski: Najwięcej krzywdy Rosjanom wyrządzili Rosjanie, http://weekend.gazeta.pl/weekend/1,152121,17796859,Dmitrij_Gluchowski_Najwiecej_krzywdy_Rosjanom_wyrzadzili.html (13.06.2019). 
daily.afisha.ru/brain/6350-o-tehnozavisimosti-228-y-state-i-ekranizaciimetro-2033/>]

Kopaliński, Władysław. Stownik symboli. t. 6. Warszawa: Rzeczpospolita, 2007.

Kowalczuk, Urszula. "Codzienność w literaturze XIX (i XX) wieku. Od Adalbeta Stifiera do współczesności,” pod red. Grażyny Borkowskiej i Anety Mazur, Opole 2007: [recenzja]", Wiek XIX: Rocznik Towarzystwa Literackiego imienia Adama Mickiewicza 2008, nr 1 (43) <http://bazhum.muzhp.pl/media//files/Wiek_ XIX_Rocznik_Towarzystwa_Literackiego_imienia_Adama_Mickiewicza/ Wiek_XIX_Rocznik_Towarzystwa_Literackiego_imienia_Adama_Mickiewicza-r2008-t1_(43)/Wiek_XIX_Rocznik_Towarzystwa_Literackiego_imienia_ Adama_Mickiewicza-r2008-t1_(43)-s149-156/Wiek_XIX_Rocznik_Towarzystwa_Literackiego_imienia_Adama_Mickiewicza-r20o8-t1_(43)-s149-156>.

Kube, Marcin. “Tekst” Gtuchowskiego: przechowalnia naszej duszy <https://www. rp.pl/Literatura/171129040-Tekst-Gluchowskiego-Przechowalnia-naszej-duszy. html>.

Orlikowski, Anna. „Wartość obcego. Fenomenologia obcego i motywy etyki przednormatywnej." Filo-Sofija 2016, no. 2(33).

Pelevin, Viktor. Betman Apollo. Moskva: Eksmo, 2013 [Пелевин, Виктор. Бэтман Аполло. Москва: Эксмо, 2013].

Przebinda, Grzegorz. Piekło z widokiem na niebo. Spotkania z Rosją 1999-2004. Kraków: Wydawnictwo Znak, 2004.

Przybysz, Anna. "Rekonfiguracja. Dmitrij Głuchowski na gruncie realizmu." Porównania 2018, no. 2(23).

Schulze, Ingo. 33 mgnienia szczęścia. Pamiętnik znaleziony $w$ drodze do Petersburga. Przeł. Kryczyńska, Anna. Warszawa: Muza, 2003.

Strukova, Marina. O romane Glukhovskogo "Tekst" <http://writervall.ru/gluhovskij-tekst/> [Струкова, Марина. О романе Глуховского “Текст" <http:// writervall.ru/gluhovskij-tekst/>].

Waldenfels, Bernhard. Podstawowe motywy fenomenologii obcego. Przel. Sidorek, Janusz. Warszawa: Oficyna Naukowa, 2009.

Węcławek, Dominika. Dmitrij Gtuchowski: Najwięcej krzywdy Rosjanom wyrzqdzili Rosjanie <http://weekend.gazeta.pl/weekend/1,152121,17796859,Dmitrij_ Gluchowski_Najwiecej_krzywdy_Rosjanom_wyrzadzili.html>.

Żakiewicz, Zbigniew. Rosja, Rosja.... Gdańsk: Polnord, 2006.

Катажина Арцишевска-Томчак

\section{КАРТИНА ПОВСЕДНЕВНОСТИ \\ В РОМАНЕ ТЕКСТ ДМИТРИЯ ГЛУХОВСКОГО}

Резюме

В данной статье рассматриваются особенности изображения повседневности в первом реалистическом романе Дмитрия Глуховского Текст. На примере судьбы главного героя произведения, Ильи Горюнова, анализируется модель русской действительности и обыденности, а также их характерные черты и атрибуты. В данном контексте особое значение приобретают категории контраста, отчуждения, фатализма и пессимистического детерминизма. 
В своем романе Глуховский представляет обыденность, ссылаясь на русский литературный дискурс. В произведении заметна инспирация автора идеями Льва Толстого, Федора Достоевского, Антона Чехова и других классиков, а также современных писателей.

Katarzyna Arciszewska-Tomczak

THE PICTURE OF RUSSIAN EVERYDAY LIFE

IN THE NOVEL TEXT OF DMITRY GLUKHOVSKY

Summary

The aricle The Picture of Russian Everyday Life $i$ The Novel Text Of Dmitry Glukhovsky describes different attribute of a everyday life and reality in contemporary Russia. The author uses the category of strangeness, contrast, fatalism and pessimistic determinism to characterize one of the most important motifs in his novel based on the life of the main character in the story. Glukhovsky shows the everyday life in Russian capital city and Moscow's area referred to works of the biggest writers of XIX century (Lev Tolstoy, Fiodor Dostoevsky, Anton Chekhov) and to contemporary Russian authors. 